\title{
The prospects \& challenges of local foods production in rural Java, Indonesia: the case of Kulonprogo Regency
}

\author{
Raden Rijanta* \\ Faculty of Geography, Gadjah Mada University, Indonesia
}

The importance of home gardens as the traditional source of local foods has been abandoned due to the new lifestyle of the young generation in Indonesia. The paper aims at examining the prospects and challenges of promoting local food as a complement to rice as staple food and to improve food security simultaneously. The paper is written on the basis of reviews of reports and focused group discussions with relevant stakeholders as well as reports from research on local food inventory and rural spatial transformation. The paper reveals that local food production in the regency have been neglected for five decades and only recently regained a new momentum for development. The promotion of local foods for improving food security are constrained by unconductive national policy (importing rice rather than promoting local foods), regional-structural factors (uncontrolled land conversions) and operational factors (ignorance of new generation on local foods).

Key Words: food security, prospects of local foods, constraints to production, home garden, Java Island, Indonesia.

Article Info: Received: August 20, 2020; Revised: November 5, 2020; Accepted: November 5, 2020; Online: November 30, 2020.

\section{Introduction}

Food security has been a crucial issue in Indonesia as a nation with the $4^{\text {th }}$ largest population in the world. The country faces various problems related to all the dimensions of food security. An international comparison using a set of data

\footnotetext{
* Correspondence address

Address: Department of Development Geography, Faculty of Geography, Gadjah Mada University, Yogyakarta, Indonesia 55281

Phone: +62 2746492331 | Email: rijanta@ugm.ac.id

(C)2020 Human Geographies; The authors

(e) $(9$

This work is licensed under a

Creative Commons Attribution 4.0 International License. DOI:10.5719/hgeo.2019.141.9
} 
provided by Intelligent Unit of the Economist (2018) shows that Indonesia ranks 65 of 113 countries, with a Global Food Security Index (GFSI) of 54.8. This partly occurs because Indonesia faces greater agricultural production volatility. Its dependency on rice production in Java is very strong, but there is also a tremendous change in land use from rice fields into other uses that lead to the decline of rice production. At the same time, rice production on the island is threatened by flood, inundation and land subsidence, especially along the north coastal regions where many small-medium sized cities are located. This worsening situation has compelled the government to rely on rice import for many decades.

The rapid urbanization and urban development in Java are particularly influenced by the growth of cities along the northern coastal region. There is even stronger pressure to develop the areas surrounding the larger metropolitan areas such as Jakarta, Bandung, Semarang and Surabaya, and this suburbanization process is characterized by the spread of urban sprawl from the core to the peripheral agricultural regions (Irawan \& Friyatno, 2012). The rice field modification into non-agricultural uses, as Sumaryanto et al., (2001) reported, has led to a decline in national food security and in the smallholders' income, a worsening occurrence of people living in poverty, a degraded rice farming culture and an abandonment in irrigation and drainage investments. Among the most threatened rice fields are the irrigated lands located on Java and Bali (53.8\%) (Khudori, 2010).

Agricultural land conversion in Java is rapidly occurring along the northern coastal region where the main rice production areas are located. The land conversions are mainly changing rice fields into other non-agricultural uses. According to the Ministry of Agriculture, there has been a decreasing amount of agricultural lands from 4.1 million hectares in 2007 to 3.5 million hectares of rice fields in 2010. The greater majority of the conversion is commonly designated to non-agricultural uses such as freeways, industrial estates, real estates, shopping centres and other public facilities (Nurwajedi et al., 2010). Tambunan (2008) shows that Java's current rice field conversion was $59.7 \%$ into urban settlement expansion and $21.8 \%$ into an industrial estate, central business areas and the development of infrastructure. Ironically, conversions of rice fields occur in the main rice production region and are situated in the arterial roads and highways. Some rice production regions in Java is also catering rice to outer islands. This means a threat to food security in here also threatens many other parts of Indonesia. The pressure for land conversion from the local government has been increasing as the decentralization policy implemented since 2000. According to Limbong (2012) decentralization policy has given city mayors and head of regencies more authorities, including also land conversion permits that led to an excessive conversion of rice fields due to the idea of increasing regional genuine revenue. Tambunan (2008) asserts that the decentralization policy has been viewed as a shortcut to increase regional revenues. Rice fields have been converted into for more commercial uses such as industries, housings and other non-agricultural uses in order to increase regional revenue almost instantly, 
neglecting the importance of the regions as a main rice production centre in Indonesia.

Following a calculation by Kompas (2011), annual rice field conversion in Indonesia has sacrificed rice production of about 14.26 million tons. The conversion of rice fields in Java Island is about 200,000 hectares annually. So far $56-60 \%$ of rice production is located in the most fertile rice fields in Java. The more significant majority of rice field conversions by the regency and municipal governments have been approved by their respective local house of representatives. The conversion process of rice fields is continuously depleting the available rice fields for the development of urban facilities such as shopping centres, office buildings, hotels, apartments, real estates, roads, manufacturing plants and warehouses.

The north coastal regions of Java that contains the most productive soil, the best irrigation systems and the most advanced agricultural development (Winoto \& Schultink, 1996) has been under threat of rapid conversion into urban expansion. The situation on the north coastal regions of Central Java nowadays is even worsened by the irreversible loss of agricultural lands due to prolonged inundation and land subsidence. This leads to a more frequent occurrence of rice harvest failures in the region. A simulation by Marfai (2011), for example, leads a very worrying situation of loss of the best agricultural land in Indonesia. The model provides two scenarios of the relationship between the depth of inundation and the coverage of inundated areas. The first scenario of $100 \mathrm{~cm}$ depth of inundation leads to a potential loss of 15 thousand hectares of agricultural lands. The second scenario of $150 \mathrm{~cm}$ depth of inundation leads to an inundated area 16 thousand hectares of agricultural lands. A potential loss of rice grain of some 90 thousand tons per year is anticipated due to this inundation and subsidence. The most affected areas of inundation and land subsidence comprise the regencies and municipals where fishponds, rice fields and dry farming areas are mostly damaged by the events.

According to Natawidjaja \& Rum (2013) food security situation of all provinces in Java is among the best in Indonesia; none of the provinces in Java is classified as food insecure. Given the fact that many provinces in Indonesia depend on food supply from Java, the failure of Java in producing various kinds of agricultural commodities may lead to a national instability. However, at the same time, there has been a policy neglect on the importance of local food production for daily consumption in the last five decades. Thus, it is important to explore the prospects of local food promotion to compensate for the irreversible loss of rice due to urbanization and land subsidence in Java.

The aim of this paper is to describe the potential of local foods in Indonesian food security situation using studies in Kulonprogo Regency, Yogyakarta Special Province where high population density occurs under the neglected role home gardens have as a local food production source. In doing so, it is relevant to explore the effects of the decreasing role of home gardens in the provision of local food for rural households, as it is historically proven that home gardens in Indonesia are among the most important locus for local food production 
(Danoesastro, 1977), (Soemarwoto et al., 1975) and (Soemarwoto \& Conway, 1992). Finally, the paper assesses the importance of land factors as constraints to local food production to substitute rice as a staple food (Rijanta et al., 2017).

The Indonesian food security Act No. 18/2012 enacts that individuals have access to adequate, diverse, safe and nutritious food that satisfies their food needs, food preferences and beliefs for an active and healthy life at all times. The law also highlights that the conditions of food security must be established mainly based on domestic production and the ability to define one's preferences for foods or food sovereignty. In an Indonesian context, food sovereignty is considered a strategy to improve food security. The concepts of food sovereignty and food security are viewed as complementing the food sector development because the two are consistent and complementary (Syahyuti et al., 2015). This view is much more simplified than those discussed in the debate on food sovereignty and food security from the work of Patel (2009). It suffices to claim that food sovereignty concept in Indonesia is a cornerstone for the revival of the contribution of local food in strengthening food security. There is also a growing awareness of the importance of local food to compensate for the loss of food supply due to land conversion, more especially the conversion of rice fields into other uses.

An early evidence of strong commitment to local food in Indonesia is research by Martianto et al. (2009) which shows that the perception of regional officials regarding the diversification of local-based food consumption is still varied and tends to focus on staple food only and has not emphasized the importance of optimizing the potential of local food. The role of local food has been perceived to be declining tremendously. The political will of regional leaders to realize the acceleration of diversification of food consumption has been categorized as good, but there has been no strong commitment to implement it. Moreover, the concept of local food itself is still subject to debates and controversies among scholars and bureaucracy.

The notion of local food itself is an essential issue for the definition of the concept. In the context of local food, there are at least three different ways of defining what is local (Kremer \& de Liberty, 2011). It includes (1) the use of circumference from a given point, (2) the use of government or other bureaucratic or political limits and (3) the use of boundaries in a food shed. Kloppenburg et al., (2006) suggest that the food shed can provide us with a place to ground ourselves in the biological and social realities of living on the land and from the land in a place we can call home, a place we are or can become native to. The use of the concept of food shed is favourable as it integrates the production and consumption of local food in an identified region. The main problem in using the concept of food shed is the difficulties in delineating its boundaries. The local consumer's purchase of local food means the local economy receives more money. This provides local farmers and traders with financial advantages and can also boost the growth of suppliers of transportation services. Food produced locally gives more freshness, maturity, flavour and often nutrition. In addition, less dependence on imported food can means increased food safety in the regency (Dumont, 2017). 
Carter-Whitney (2009) has reported that systemic barriers, such as legislation, regulations or international agreements, are major obstacles in local food production and consumption. In parallel, the institutional factor is also seen as a barrier. The long-chain from farmers to groceries hampers the urban population's consumption of local food commodities. Also, in line with these barriers, Martinez et al. (2010:iv) assert that "barriers to local food-market entry and expansion include: capacity constraints for small farms and lack of distribution systems for moving local food into mainstream markets; limited research, education, and training for marketing local food; and uncertainties related to regulations that may affect local food production, such as food safety requirements".

In view of the problems of continuous price growth worldwide, local food crops are considered important alternatives (Bellows \& Hamm, 2001). National agricultural development policy has had a strong bias towards rice production as a staple food in Indonesia. Over the past 50 years, local food crops have been neglected in the agricultural development policy, leading to dependence on imported food commodities and creating vulnerability in national food security.

\section{Methodology}

The paper was written based on researches on (1) Inventory and Mapping of Local Food in Kulonprogo Regency in 2012 sponsored by the Research Institute of Gadjah Mada University through Institutional Research Scheme (Rijanta et al., 2012) and (2) Modelling Rural Space Transformation in Fast-growing Coastal Regions of Yogyakarta Special Province (2017-2019) supported by the Ministry of Research and Higher Education of the Republic of Indonesia through Basic Research Scheme (Rijanta, et al., 2017).

In the first research, various information on local foods availability, utilization and constraints in the regency were derived from the research report as well as the raw data. The outcomes of Focused Group Discussion in 2012 were used to explain various constraints for promoting local food to improve food security at the community level in the regency. The focus group discussions were attended by the representative of local offices on agriculture, food security, public works, the local planning authority, trade and cooperatives, education and culture. Local NGO's dealing with local foods was also actively contributing various information on the practices of local food utilization at community level.

The second research provides information related to structural constraints for the promotion of local foods in the regency. Data related to the agrarian structure and farmer regeneration of the regency were extracted from the statistical data sets, reports and raw primary data sets. Structure of land tenure by size, dynamics of land use, and trend of land conversion towards non-agricultural use were obtained from various documents and reports. The paper also makes use a set of raw data on farmer regeneration that enables an assessment of the future prospect 
of local food production to improve food security in the regency. Detailed information on research methods, data and data analysis is provided in Table 1.

Table 1. Methods, Data and Analysis Used in the Researches for Writing the Paper

\begin{tabular}{|c|c|c|}
\hline $\begin{array}{c}\text { Research } \\
\text { Methods Used }\end{array}$ & Data Obtained & Process of Analysis \\
\hline $\begin{array}{l}\text { Content } \\
\text { analysis }\end{array}$ & $\begin{array}{l}\text { The content of regulation on } \\
\text { local foods }\end{array}$ & $\begin{array}{l}\text { Extracting the content of regulation } \\
\text { on local foods }\end{array}$ \\
\hline \multirow[t]{4}{*}{$\begin{array}{l}\text { Secondary } \\
\text { data analysis }\end{array}$} & $\begin{array}{l}\text { Land use composition in the } \\
\text { regency }\end{array}$ & Map reading and interpretation \\
\hline & Population growth & Calculation of geometric growth \\
\hline & Household growth & Calculation of geometric growth \\
\hline & $\begin{array}{l}\text { Structure of house building } \\
\text { cost }\end{array}$ & $\begin{array}{l}\text { Calculation of relative contribution } \\
\text { of land price in house building const }\end{array}$ \\
\hline \multirow[t]{3}{*}{$\begin{array}{l}\text { Rapid Rural } \\
\text { Appraisal }\end{array}$} & $\begin{array}{l}\text { Practices of local food crop } \\
\text { production across the regency }\end{array}$ & $\begin{array}{l}\text { Field observation and in-depth } \\
\text { interviews with relevant resource } \\
\text { persons }\end{array}$ \\
\hline & $\begin{array}{l}\text { Practices of local food crop } \\
\text { utilization across the regency }\end{array}$ & $\begin{array}{l}\text { Field observation and in-depth } \\
\text { interviews with relevant resource } \\
\text { persons }\end{array}$ \\
\hline & $\begin{array}{l}\text { Flows of local food crop } \\
\text { marketing and transportation }\end{array}$ & $\begin{array}{l}\text { Field observation and in-depth } \\
\text { interviews with relevant resource } \\
\text { persons }\end{array}$ \\
\hline \multirow[t]{3}{*}{$\begin{array}{l}\text { Focus Group } \\
\text { Discussion }\end{array}$} & $\begin{array}{l}\text { Commitment of local } \\
\text { government in encouraging }\end{array}$ & $\begin{array}{l}\text { Extraction of information from the } \\
\text { focus group discussion }\end{array}$ \\
\hline & $\begin{array}{l}\text { the production and } \\
\text { consumption of local foods }\end{array}$ & \\
\hline & $\begin{array}{l}\text { Various challenges in the } \\
\text { production and consumption } \\
\text { of local foods at household and } \\
\text { regional levels }\end{array}$ & $\begin{array}{l}\text { Categorization of challenges in the } \\
\text { production and consumption of } \\
\text { local foods }\end{array}$ \\
\hline \multirow[t]{2}{*}{$\begin{array}{l}\text { Crop } \\
\text { inventory }\end{array}$} & $\begin{array}{l}\text { Records of names of local food } \\
\text { crops in all villages in the } \\
\text { regency }\end{array}$ & Categorization of crops \\
\hline & $\begin{array}{l}\text { Maps of the regionalization of } \\
\text { local food crop in the regency }\end{array}$ & $\begin{array}{l}\text { Extraction of spatial patterns of } \\
\text { existing local food crops }\end{array}$ \\
\hline \multirow{2}{*}{$\begin{array}{l}\text { Household } \\
\text { survey using } \\
\text { questionnaires }\end{array}$} & $\begin{array}{l}\text { Composition of farmers by age } \\
\text { groups }\end{array}$ & Categorization of farmers age \\
\hline & $\begin{array}{l}\text { Readiness of other household } \\
\text { members to continue farming }\end{array}$ & $\begin{array}{l}\text { Categorization of readiness of other } \\
\text { household members to continue } \\
\text { farming }\end{array}$ \\
\hline
\end{tabular}

Source: Compiled from Rijanta et al. (2012) and Rijanta et al. (2017).

\section{Results and Discussions}

\section{New awareness of the importance of local food}

In 2009, the head of the Kuloprogo Regency in Yogyakarta Special Province decreed that all governmental bodies in this region use local food in official 
activities. The decree was based on the fact that there is a need to accelerate the diversification of food, and this should be fulfilled by a movement to produce and consume locally-produced foods. This decree reflects a strong political will from the local government and provides an umbrella for implementation of local food production and consumption in the regency. This local initiative is now extended to cover the use of brown sugar produced from the locally abundant coconut trees, the consumption of cassava as a primary carbohydrate source (in which the head of regency plays as a role model), the use of local rice in the national program of rice for the poor in the regency and the consumption of locally produced bottled drinking water by the regency water company. The step to strengthen local foods to fulfil the availability dimension of food security has been considered a progressive local initiative as the corresponding national law was only issued 3 years later. The local government of Kulonprogo also compels the nation-wide modern market operating in the regency to sell locally made commodities and rename their national brands according to local circumstances.

As mentioned in the document on long and medium-term development planning, the Government of the Kulonprogo Regency has declared its commitment for developing local foodstuffs as part of its agricultural development policy (Rijanta et al., 2013). This new commitment shows a sharp change in policy as some local food crops were forbidden by the past government. In the 1980s, Kulonprogo Regency local governments banned the cultivation of certain types of plants which were considered to cause health and esthetic problems in the village. Garut (marantha arundinacea) and ganyong (canna edulis) were among the forbidden plants because their bushes were regarded as a potential mosquito breeding ground. The production of garut and ganyong has decreased substantially, even in many rural areas of the regency the plants are now very difficult to find. In the past, these plants have been seen as alternative sources of carbohydrate. In contrast, garut and ganyong flour is currently regarded as nutritious food to replace rice as a carbohydrate source. Consequently, local farmers are unable to meet the demands of this foodstuff. Also, in the past, certain villages even prohibited bamboos along the roads, as their accumulated falls can disturb the beauty of the village. Evolution of policy concerning local food in Indonesia, especially in Kuloprogo Regency, is descrived in Table 2 as follow.

\section{Declining role of home garden in the production of local food}

The rice field is not the only Indonesian food production site. Traditionally, the home garden or the local so-called pekarangan, cultivated land where the house is built, provides a significant proportion of the food of each household. Contrary to the rice field, the production of a home garden is much more diversified and reliable, and necessarily more stable and sustainable (Soemarwoto et al., 1975). Furthermore, rural poor people benefit more from home gardens. 
Table 2. Evolution of policies related to local food in Kulonprogo Regency, Indonesia (Pre1980 - Present)

\begin{tabular}{|c|c|c|c|}
\hline $\begin{array}{l}\text { Aspects to } \\
\text { Compare }\end{array}$ & Pre-1980s & $1980 s-2009$ & 2009 - present \\
\hline $\begin{array}{l}\text { National } \\
\text { agricultural } \\
\text { development } \\
\text { policy }\end{array}$ & $\begin{array}{l}\text { - Agricultural } \\
\text { development policy is } \\
\text { strongly biased towards } \\
\text { self-sufficiency in rice } \\
\text { through a centralized } \\
\text { decision-making process } \\
\text { - Weak local governments } \\
\text { - Import of rice continues } \\
\text { from the past } \\
\text { government }\end{array}$ & $\begin{array}{l}\text { - Rice sufficiency was } \\
\text { achieved in } 1984 \text { (only) } \\
\text { - Import of rice } \\
\text { continues } \\
\text { - Initiation of } \\
\text { agricultural } \\
\text { diversification } \\
\text { - New lifestyle emerges } \\
\text { due to globalization } \\
\text { and socio demographic } \\
\text { changes }\end{array}$ & $\begin{array}{l}\text { - Import of rice continues } \\
\text { - Agricultural diversification } \\
\text { is promoted } \\
\text { - Stronger local government } \\
\text { since the enactment of } \\
\text { decentralization in } 2000 \\
\text { - Enactment of local food } \\
\text { regulation (2012) nation } \\
\text { wide }\end{array}$ \\
\hline $\begin{array}{l}\text { Regency } \\
\text { policy and } \\
\text { local food } \\
\text { conditions }\end{array}$ & $\begin{array}{l}\text { - Local foods were } \\
\text { important contributor to } \\
\text { rural household food } \\
\text { supply and exchange } \\
\text { among rural households } \\
\text { - Home-garden as a } \\
\text { center for food } \\
\text { production } \\
\text { - Import of rice continues } \\
\text { from the past } \\
\text { government }\end{array}$ & $\begin{array}{l}\text { - Prohibition of some } \\
\text { local food crops as they } \\
\text { disturbed the village } \\
\text { beauty or believed to } \\
\text { be mosquito breeding } \\
\text { places } \\
\text { - Shifting to rice as staple } \\
\text { food } \\
\text { - Growing consumption } \\
\text { of fast/ manufactured } \\
\text { food } \\
\text { Import of rice and } \\
\text { neglect of local foods }\end{array}$ & $\begin{array}{l}\text { - Enactment of regulation } \\
\text { on the promotion of local } \\
\text { foods (2009) } \\
\text { - Implementation at regency } \\
\text { level varies in forms and } \\
\text { success } \\
\text { - Growing spirit to } \\
\text { reconsider the local as } \\
\text { oppose to imported foods } \\
\text { - Constraints to local food } \\
\text { promotion from structural } \\
\text { to operational factors }\end{array}$ \\
\hline
\end{tabular}

Source: Compiled from Various Sources, 2020

Central Java has been suggested to be the Indonesian home garden centre in its present, highly developed form. Since home gardens are mainly taken care of by women, they tend to evolve among matriarchal societies that were typical of Central Java thirty years ago. In the West Sumatran matriarchal society and among North Sumatra Acehnese, but not among patriarchal Batak peoples, also from North Sumatra, well-developed home gardens are similarly to be found (Penny \& Ginting 1984). Since the initiation of Indonesia's first of its five-year successive development plans, the number of upper and medium class people who can afford high-quality housing and nutrition has increased substantially. As a result, the demand for better quality fruit and vegetables has increased, and home gardens responded with an improvement in product quality, by choosing the high-demand varieties and species. Traditional Javanese home gardens, where most local foods are produced, have several desirable features. Although productivity is relatively low per hectare, they tend to work largely outside the market economy to satisfy a broad range of domestic demands cheaply. The local food contributes substantially to supplement the diet and income of the communities, especially during the critical period between rice harvests. They are a valuable genetic resource and protect against soil erosion. Home gardens are generally a stable and extremely sustainable system (Soemarwoto et al., 1975). A more recent research by Widiyanto et al. (2014) reveals that there is evidence that poorer households can benefit from trade in local cooked food when the supply 
is readily available in the market. Data showed that prepared local food is worth more than twenty times compared to the raw products. As an example, the price of raw arrowroots is worth $\mathrm{Rp} 1,000,00$ per kilogram, and it would increase up to Rp 25,000,00 per kilogram when it processed to become arrowroot chips. In order to reduce poverty, this practice needs support from various stakeholders. But, these desirable characteristics of Javanese home gardens are now under threat. Various types of new plants and animals are preferred to increase productivity because of their high market value, while species and variety are decreasing.

The consequences will include severe loss of genetic resources in parallel with rice; loss of the structure of the layered canopy and the litter, and increased potential soil erosion; loss of the system of recycling which results in high fertilization inputs; loss of natural pesticide control agents which leads to pesticide use; loss of production stability within and between years; loss of a wide variety of nutrients; and finally, ending the culture of sharing products with relatives and neighbours. In order to address the global escalation of food prices, local food commodities are considered an important alternative. Rice production appeared to be a significant ingredient in rural development in Indonesia through job creation in staple food production. The development of local foods has over the past 50 years been neglected in agricultural development policies, resulting in a large dependency on imported food products and new vulnerability in the system of domestic food security (Soemarwoto et al., 1975). More recent research by Hardono (2014) reveals that more people have consumed local food but are still in relatively small portions and they do not do it routinely, so they have not been able to substitute the main staple food consumption, namely rice. Local food sources of carbohydrates, such as cassava and corn, are mostly served in the form of snacks. Local food consumption preferences usually increase when rice prices increase. However, when purchasing power strengthens, people tend to choose rice as their staple food.

Studies reveal that in the Kulonprogo Regency, at least 49 types of local food crops are known. Many of these plants are only known to the elderly (Rijanta et al., 2013). There is minimal knowledge of these crops among the young generation in rural areas. Due to the existing knowledge of the regency's local food crops, it is in doubt whether the farmers are prepared to rethink local food production. Without the knowledge-based decision of farmers, the strong political will of the local government to initiate the new program for local food development will not succeed. The Government of Kulonprogo Regency has committed to boost the promotion of local food commodities as part of agricultural sector development policy. The regulation obliges local food products to be used in all meetings and events organized by the local government. Research in Kulonprogo Regency (Rijanta et al., 2013) has shown that local food crop production in the regency has been constrained by at least 6 regionalstructural matters and by 9 local-operational variables (Figure 1). Local foods that have been neglected for decades are presently know and consume only among the elderlies. 
Knowledge of local food among the young generation is simply insufficient or absent; they have an opinion that foods consumed only by the older generation are something old-fashioned, inferior and no-pride. Many local food commodities are mostly available only during the dry season and consumed mostly locally, and no sizeable processing plants are presently known. Many of the local foods are processed at a household level simply to the extent of their durability. Meticulous processing is necessary as some of the local food crops such as gadhung (dioscorea hispida), suweg (amorphophallus paeoniifolius) and benguk (mucuna pruriens) are poisonous when they are not well processed according to specific local knowledge. Difficulties in processing and risk of contagion of some of the commodities may have led to the present neglect of these local foods. As a consequence of the seasonality, low production and low productivity level of the foodstuff, there is no strong drive for the development of processing technology. Thus, technical knowhow in local food production and processing is simply absent, and the present production and processing are conducted with outdated technologies.

The problems faced by the local foods is also related to the late or absence farmer regeneration, where many old farm household heads reported that there are no family members to continue to farm due to urbanization. This is also the case of farmers in the production of local foods. The production of local foods in the regency is also faced with high variability of price, as the supply is limited, but occasionally demand is very high. Demand for local foods usually increases when the price of rice is rising due to disasters, harvest failures or crises, so many people substitute rice with various local food commodities. Thus, it is consistent with the fact that many people consider the position of local foods as secondary products. They are usually consumed only in the case of an emergency. Finally, the existing low production and productivity of local foods further give uncertainties in the availability of commodities in the market and uncertainties in demands as well. Many small-scale industries in the regency cannot rely on the harvest of local food commodities for their inputs.

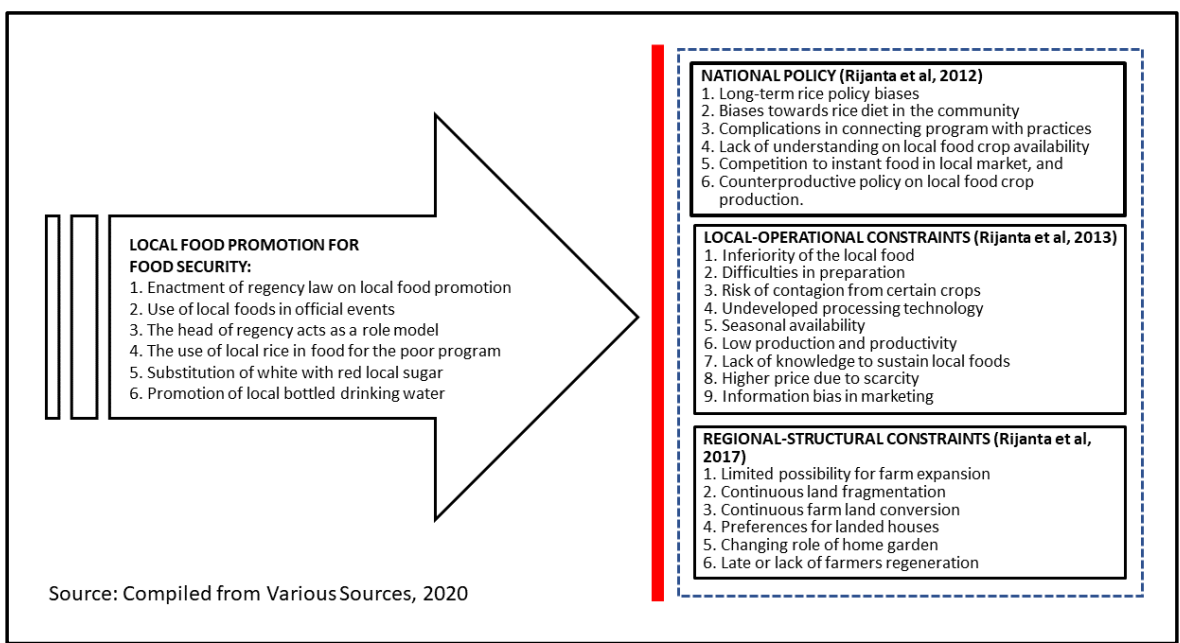

Figure 1. Conceptual Model of Constraints to Local Food Promotion for Food Security in Kulonprogo Regency, Indonesia 2019 


\section{Regional-structural factors challenging local food production}

Lands as the main production factors in densely populated areas like Java Island become the most competitively demanded resources for agricultural production, settlements, infrastructure, industrial parks and urban expansion. Once the need for lands for non-agricultural uses is raising through an investment proposal by the government of the private sector in the vicinity of a regency capital, agricultural lands are sacrificed to fulfil the demand. Under the decentralization policy launched in 2000, fertile irrigated lands surrounding cities have been increasingly converted to non-agricultural uses in order to achieve higher regional revenue. The detailed regional-structural constraints to local food production is shown in Figure 1, especially in the bottom-right box. A more elaborated account on the regional-structural factors in constraining food production in Java is presented as follows:

1. Limited possibility to expand rice fields, zero-sum game in rice production at the cost of loss of many other commodities

The Indonesian government is now committed to expanding irrigated lands to increase rice production through the dams construction and their irrigation networks across the country. Many of the dams constructed in highly populated islands like Java would simply lead to a situation of conversion from non-irrigated to irrigated lands. Thus, the increasing areas for rice cultivation are attained at the cost of dry agricultural lands where most local food production takes place. In Kulonprogo Regency, on the one hand, a substantial expansion of irrigated lands has been obtained since 1996 following the operation of Sermo Dam, on the other hands the amount of land conversion from agricultural to non-agricultural uses are almost two-fold in comparison to the obtained of irrigated lands. This means that an effort to increase rice production in a populated region can easily be counterbalanced by the conversion of agricultural lands into non-agricultural uses. Increasing the coverage of area under irrigation is a good but not enough solution to improve agricultural production and food security in a densely populated area with high intensity of rice field conversion.

2. Continuous fragmentation of farmlands (diseconomy of scale on local food production)

Given the lack or absence of regulation concerning minimum land parcel in many regencies and municipalities in Indonesia, the process of land fragmentation is continuously going through inheritance and collective purchase. Fragmentation of agricultural lands is partly occurring as consequences of the process of inheritance from parents to their siblings. Given the smaller Indonesian family size attained through family planning program in the past, inheritance process may lead to smaller size of lands. The collective purchase of lands for housings by a group may lead to an extreme fragmentation of large parcel into smaller size affordable for housing by the younger people. This situation mostly happens in the surrounding areas of growing cities where many young families are in need of landed houses. The process of extreme fragmentation of this type is frequently facilitated by land brokers. The smaller size of lands for home gardens has led to an unfeasible size for food crop 
production even for their own consumption. The image of the home garden as a source of food could not be maintained, as it has changed toward the new image of home garden as decorative gardens.

3. Strong cultural preferences of landed houses have stimulated further agricultural land conversion

Landed houses are much preferred by Indonesian families who were originally rural. Given the tightened competition among land uses in the surrounding urban areas of Indonesia, the preference toward landed houses has led to high demands for lands for housings and unavoidable agricultural land conversion. The continuously growing land prices in the surrounding areas of Indonesian cities may lead to uncontrolled urban sprawl and land fragmentation. New urban settlers always face a trade-off between living in the city with higher house price but lower transportation cost or living in the countryside with lower house price but higher transportation cost. This situation happens as land price comprises the main production cost of urban housing in Indonesia. Between 60$70 \%$ or more of the current house price in Indonesia are the cost for land procurement, depending on location and types of houses. Due to the quickgrowing value of properties in the urban areas, many of the landed houses are constructed and marketed for speculation that gives a return of more than $15 \%$ per annum. This situation leads to even worse conversion of agricultural lands. Given the fact that the household growth (1.67\% per annum) is slightly higher than population growth ( $1.49 \%$ per annum), this trend will continue for at least 10-20 years to come.

4. Decreasing intensity of the role of the home garden as sources of food stuff

Home garden of Javanese families used to be large and very densely planted with many kinds of crops for domestic uses. Until the 1980s home gardens in Java was a main source of vegetables, fruits, herbs and staples (Danoesastro, 1977; Soemarwoto et al., 1975). The new preference towards smaller size and nuclear families has led to a tremendous change in the use of home gardens. Houses and its gardens are commonly much smaller but constructed with more durable materials. Home gardens are typically small, and no food production can be made with present-day farming techniques. Decorative plants are more commonly encountered than food crops. For households with an old and larger size of houses and home garden, production of food in the home garden has been commonly abandoned. Ageing farmers and the lack of young people to farm in many villages has led to the declining production of local food to substitute and/or to complement rice within the context of improving food security.

5. Slow or lack of a process of farmer regeneration

Regeneration of farmers in Indonesia is very slow or stagnant as many young people are not interested in farming. Rijanta (2006) shows that the young generation is much more interested in doing casual and temporary jobs in the city rather than farming in their villages. Farming is considered to be secondary employment by many rural dwellers of Bantul in Yogyakarta Province. Removal of fertilizer subsidy, import of rice and payment of irrigation fee are among policies that discourage the participation of the younger generation to farm. The 
only exception is in some spots of commercial agricultural of the province where significant number of young farmers have a strong commitment to farm as primary employment. This is the case of the area of salak (salacca zalacca) production where many young farmers are eager to continue farming like their parents. More recent research (Rijanta, 2018) maintains that there is a lack of farmer regeneration in the rural areas of the regency. Less than one-third of the surveyed rural households (12 out of 41 ) have their offsprings continue farming.

\section{Conclusion}

Albeit food security situation in Java Island is among the highest in Indonesia at present, the richness of home garden as the centre for the local food commodities has been neglected for decades. At the same time, Java Island as the main supplier of rice to many parts of the country has been threatened by land conversion for urbanization and irreversible loss of farmlands due to permanent inundation and subsidence along the north coastal regions. There is a stumbling block of the continuity of production of rice as a staple food due to land conversion for urban expansion, infrastructure development, housings, industrial estates, commercial and non-commercial facilities. Local food production has a strong prospect for two reasons, namely (1) historical evidence in the richness of the variety of commodities and importance of local foods for daily consumption in the past and (2) new spirit and firm policy supports from the local government to reintroduce the local food to strengthen food security. The prospects for the promotion of local foods are constrained by unfavourable national agricultural development policy from the past, regional-structural factors and local-operational factors.

The contribution of local food in food security improvement is challenged by many socio-economic and political factors such as centralized decision-making process in agricultural development. At the same time, socio-economic transformation due to globalization and socio-demographic changes at the community level in the last 50 years has led to new lifestyle and preferences toward a smaller size family, landed houses and new types of food obtained from other parts of the country or abroad through international and interregional trades. Even in the small rural community in Kulonprogo Regency, the consumption of food from other parts of the country are the rule rather than the exception. Local food can be a vital component to improving food security, but under the lack of effective measure from the government side, it is not feasible to expect its real contribution to improving food security in the near future.

\section{Acknowledgement}

The paper was written based on researches on (1) Inventory and Mapping of Local Food in Kulonprogo Regency in 2012 supported financially by the Research Institute of Gadjah Mada University through Institutional Research Scheme and 
(2) Modelling Rural Space Transformation in Fast-growing Coastal Regions of Yogyakarta Special Province (2017-2019) sponsored by the Ministry of Research and Higher Education of the Republic of Indonesia through Basic Research Scheme.

\section{References}

Bellows, A.C. and Hamm, M.W. (2001), "Local Autonomy and Sustainable Development: Testing Import Substitution in More Localized Food Systems", Agriculture and Human Values, vol. 18, no. 3.

Carter-Whitney, M. (2009), Bringing Local Food Home: Legal, Regulatory and Institutional Barriers to Local Food, The Greenbelt Foundation, Toronto.

Danoesastro, H. (1977), "Peranan Pekarangan dalam Usaha Meningkatkan Ketahanan Nasional Rakyat Pedesaan", Pidato Dies Natalis Universitas Gadjah Mada XXVIII, Universitas Gadjah Mada, Yogyakarta.

Dumont, A. (2017), The Economic Impact of Locally Produced Food, Federal Reserve Banks of St. Louis, 25 March 2020, shorturl.at/qrFZ5.

FAO (2001), "Land and Water Resources Development in Indonesia", Proceedings of the Regional Consultation BANGKOK, Thailand 3-5 October 2001, Food and Agriculture Organization of the United Nations, Bangkok, 12 March 2002, shorturl.at/eP024.

FAO (2003), WTO Agreement on Agriculture: The Implementation Experience Developing Country Case Studies, 20 March 2020 shorturl.at/cyY38.

Hardono, G.S. (2014), "Local Food Diversification Development Strategy", Analisis Kebijakan Pertanian, vol. 12, no. 1, Juni 2014, 1-17.

Intelligence Unit of the Economist (2018), 2018 Global Food Security Index, The Economist. London.

Khudori, (2010), "Kondisi Pertanian Pangan Indonesia", Pangan, vol. 19, no. 3, p. 211-232.

Kompas, (2011), Konversi Lahan Makin Tidak Terkendali, 15 March 2020, shorturl.at/msxB0.

Kremer, P. and de Liberty, T. (2011), "Local Food Practices and Growing Potential: Mapping the Case of Philadelphia", Applied Geography, vol. 31, p. 12521261.

Limbong, B. (2012), "Politik Pertanahan dan Otonomi Daerah", Harian Suara Pembaharuan, Tanggal, May $22^{\text {nd }}$.

Marfai, M.A. (2011), "The Hazards of Coastal Erosion in Central Java, Indonesia: An Overview", Malaysia Journal of Society and Space, vol. 7, no. 3, p. 1-9.

Martianto, D., Briawan, D., Ariani, M. and Yulianis, N. (2009), "Food Consumption Diversification Acceleration based on Local Food: Local Stakeholders Perspectives and Strategies to Achieve", Jurnal Gizi dan Pangan, vol. 4, no. 3, p. 123 - 131 . 
Martinez, S., Hand, M., Da Pra, M., Pollack, S., Ralston, K., Smith, T., Vogel, S., Clark, S., Lohr, L., Low, S. and Newman, C. (2010), "Local Food Systems Concepts, Impacts, and Issues", USDA Economic Research Report, no. 97, p. 1-17. Natawidjaja, R.S. and Rum, A.I. (2013), Food Security Situation and Policy in Indonesia. Bandung: Center for Agrifood Policy and Agribusiness Studies, Padjadjaran University.

Nurwadjedi, B.M and Poniman, A. (2010), "Assessment of the Rice Field Sustainability in Java on the Basis of Regional Planning (RTRW)", Jurnal Ilmiah Geomatika, vol. 16, no. 1.

Patel, R. (2009), "Food Sovereignty", The Journal of Peasant Studies, vol. 36, no. 3.

Penny, D.H. and Ginting, M. (1984), Homegarden, Peasant and Poverty, Gadjah Mada University Press., Yogyakarta.

Rijanta, R. (2006), "Rural Livelihood Diversification in Yogyakarta Special Province, Indonesia", School of Graduate Studies, Gadjah Mada University, Yogyakarta, Unpublished Ph.D. Thesis.

Rijanta, R. (2018), "Sustainability of the Sawah Surjan Agricultural Systems in Depok Village, Panjatan Subdistrict, Kulonprogo Regency, Yogyakarta Special Province", Forum Geografi, vol. 32, no. 2.

Rijanta, R., Baiquni, M. and Rachmawati, R. (2017), Model Transformasi Ruang Perdesaan di Wilayah Tumbuh Cepat Pesisir Daerah Istimewa Yogyakarta, LPPM UGM, Yogyakarta.

Rijanta. R., Widiyanto, Dodi, Sulistyani, Sri and Toekidjo, Toekidjo (2013), "Factors Constraining Local Food Crop Production in Indonesia: Experiences from Kulonprogo Regency, Yogyakarta Special Province", Romanian Review of Regional Studies, vol. IX, no. 1.

Soemarwoto, O. and Conway, G.R. (1992), "The Javanese Home Garden", Journal for Farming Systems Research-Extension, vol. 2, no. 3, p. 95-118.

Soemarwoto, O., Soemarwoto, I., Karyono, Soekartadiredja, E.M. and Ramlan, A. (1975), "The Javanese Home-Garden as an Integrated Agro-Ecosystem", Science for Better Environment. Proceedings of the International Congress on the Human Environment (HESC), Kyoto, p. 193-197.

Suprastyo, D. (2018), "Analisis Distribusi Pemilikan Lahan Pertanian dan Pendapatan Usahatani Padi di Kabupaten Karawang". Unpublished Ph.D. Thesis, Institut Pertanian Bogor.

Syahyuti, Sunarsih, Sri, W., Wahyuning, K.S. and Miftahul, A. (2015), "Kedaulatan Pangan Sebagai Basis untuk Mewujudkan Ketahanan Pangan Nasional", Forum Penelitian Agro Ekonomi, vol. 33, no. 2, p. 95-109.

Tambunan, T. (2008), Ketahanan Pangan di Indonesia: Mengidentifikasi Beberapa Penyebab, Pusat Studi Industri dan UKM, Universitas Trisakti, Jakarta.

Winoto, J. and Schultink, G. (1996), "Impacts of Urbanization on Agricultural Sustainability and Rural Life in West Java, Indonesia", Research Report Number 545, Department of Resource Development Michigan State University East Lansing, USA. 